\title{
Diversity of terrestrial snails and slugs in Nee Soon freshwater swamp forest, Singapore
}

\author{
W.H. Lim ${ }^{1,2}$, T.J. $\mathrm{Li}^{1} \&$ Y. Cai ${ }^{1}$ \\ ${ }^{1}$ National Biodiversity Centre, National Parks Board, \\ 1 Cluny Road, 259569 Singapore \\ cai_yixiong@nparks.gov.sg \\ ${ }^{2}$ Current address: The Herbarium, National Parks Board, \\ 1 Cluny Road, 259569 Singapore
}

\begin{abstract}
Nee Soon freshwater swamp forest is the last remaining primary freshwater swamp forest left in Singapore and it contains a rich diversity of native and locally threatened fauna. As native terrestrial snails and slugs are poorly studied and understood in Nee Soon freshwater swamp forest, an extensive survey was conducted to establish their current status. A total of 19 species was recorded, of which one was recorded for Singapore for the first time. Amphidromus atricallosus temasek, a recently described subspecies endemic to Singapore, was found to be more commonly distributed than previously known from the swamp forest. Results also indicate that despite low overall abundance, Nee Soon freshwater swamp forest harbours a rich diversity of land snails and slugs. Any future long term changes in climate or topography, or short term changes in hydrology, might affect their distribution and diversity.
\end{abstract}

Keywords. Land molluscs, Mollusca, species richness

\section{Introduction}

Nee Soon freshwater swamp forest is one of the most important conservation sites in Singapore and contains a significant number of native, endemic and nationally threatened flora and fauna ( $\mathrm{Ng} \& \mathrm{Lim}, 1992$; Ng, 1997; Clews et al., 2018). The forest is located within the Central Catchment Nature Reserve, bordered by the Upper Seletar Reservoir to the north, Seletar Expressway and Old Upper Thomson Road to the east, Upper and Lower Peirce Reservoirs to the south, and the southwestern tributary of the Upper Seletar Reservoir and the northern-most tributary of the Upper Peirce Reservoir to the west (Yeo \& Lim, 2011). The forest consists of primary and old secondary vegetation, the stream catchment covering an area of approximately 500 hectares.

To date, a total of 51 terrestrial snail and slug species (and subspecies), representing 33 genera in 15 families, have been recorded in Singapore (Ho, 1995; Tan \& Chan, 2009; Tan \& Woo, 2010; Tan et al., 2011; Tan et al., 2012; Tan \& Chan, 2013). Many of these species are considered to be forest dependent, recorded mainly in the Singapore Botanic Gardens rain forest, Central Catchment Nature Reserve (including Nee Soon freshwater swamp forest) and Bukit Timah Nature Reserve. Forest dependent species include Cyclophorus perdix aquila, Cyclotus rostellatus, Ditropis cf. koperbergi, Japonia ciliocinctum, Diplommatina nevilli, Microparmarion 
strubelli, Hemiplecta humphreysiana, Dyakia kintana, Amphidromus atricallosus temasek and Amphidromus inversus. There has been no comprehensive information on the terrestrial snail and slug species found in Nee Soon freshwater swamp forest, even during the last extensive biodiversity survey of the nature reserves conducted in 1993-1997. Therefore, this study aims to provide baseline information on the biology and distribution of terrestrial snails and slugs within Nee Soon. This information will be useful in updating the status of individual species and will contribute to the design of conservation efforts for the freshwater swamp forest.

\section{Material and Methods}

Quantitative hand picking sampling was carried out from September 2013 to October 2015 in 15 plots spread broadly across the Nee Soon catchment in four different areas: Upper Swamp (Upper 1 \& 2 Sub-catchments), Middle Swamp (Mid 1-3 Subcatchments), Lower Swamp (Lower 3 Sub-catchments) and Outskirts (Lower 1 \& 2 Sub-catchments) (Fig.1). The plots were sampled repeatedly for six collection cycles. Each plot consisted of two $10 \times 5$ m quadrats. Each quadrat was searched thoroughly by two people for half an hour to locate any snails or slugs. Most of the specimens were found on the forest floor, hidden within the leaf litter or up on the trees, on the underside of leaves. Shell height, width and chirality were recorded at time of collection. Shell height was measured from the apex to the lowest part of the outer lip parallel to the coiling axis and shell width was measured at the widest part of the body whorl perpendicular to the coiling axis. Body length was recorded for slugs. Temperature and humidity were also measured at each site and summarised in Table 1.

The Shannon-Weiner Index (H') was used to study and compare species diversity at each site. The equation for the Shannon-Weiner Index is as follows:

$$
H^{\prime}=-\Sigma\left(P_{i} \log \left[P_{i}\right]\right)
$$

where $\mathrm{P}_{\mathrm{i}}=$ number of individual species / total number of individuals

\section{Results}

\section{Family CYCLOPHORIDAE}

Cyclophorus perdix aquila (Sowerby, 1843), Fig. 2A

Cyclophorus perdix aquila is one of several forest land snail species that survive in Singapore's rainforests. Species from Cyclophoridae require moisture to be secreted on the surface of the mantle cavity to aid in respiration, thus most of them are restricted to areas that are wet and moist (Tan et al., 2012). All specimens were found near to forest streams or swampy areas. 


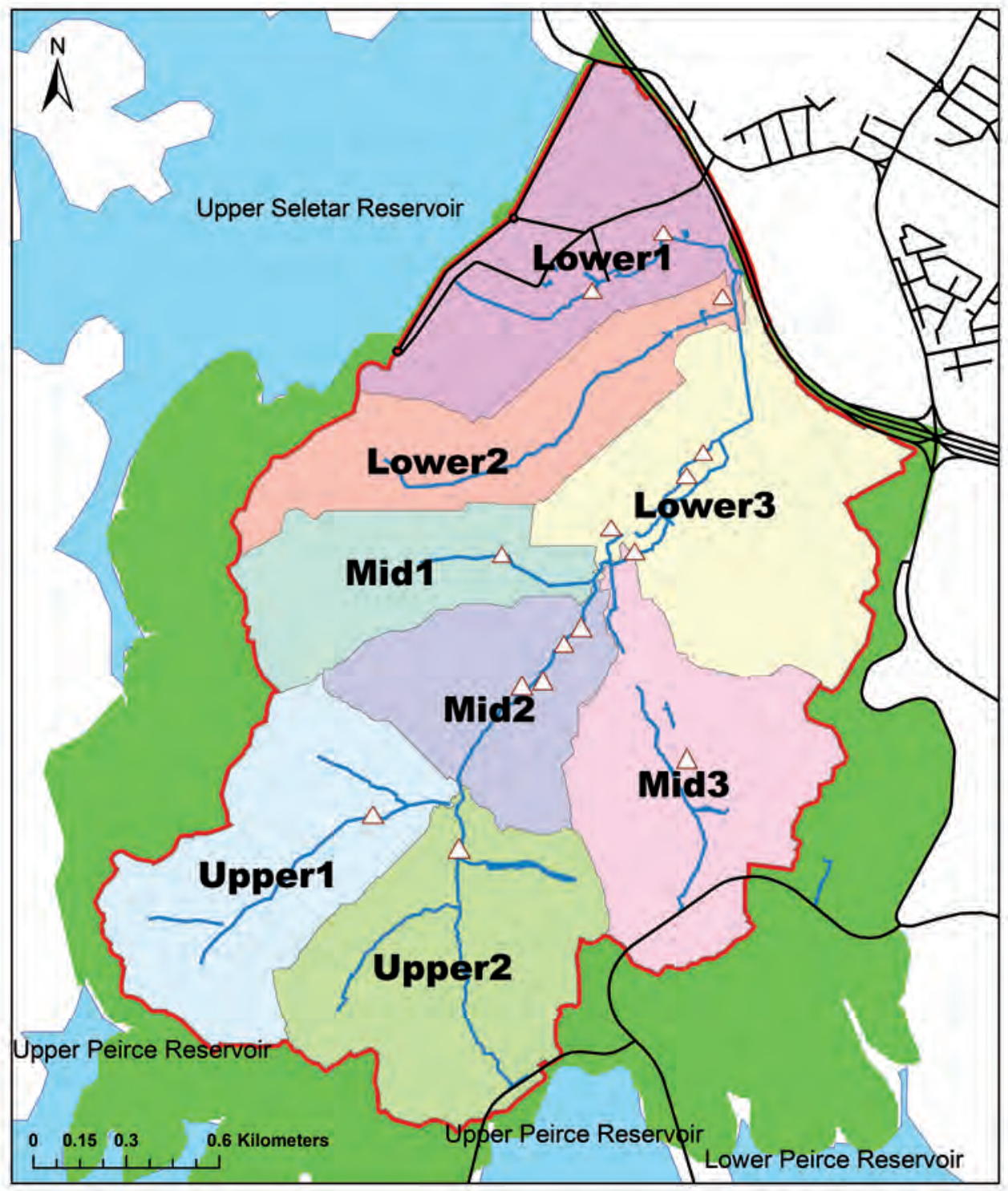

\section{Legend}

\section{$\triangle$ Sampling site \\ Stream}

Nee Soon forest boundary

Catchment boundary

Fig. 1. Map of sampling plots in Nee Soon freshwater swamp forest. 
Table 1. Mean temperature and humidity of the sampling plots.

\begin{tabular}{lcc}
\hline Site & Humidity (Mean) & $\begin{array}{c}\text { Temperature } \\
\text { (Mean) } /{ }^{\circ} \mathrm{C}\end{array}$ \\
\hline Upper Swamp 1 & 76.08 & 29.46 \\
Upper Swamp 2 & 78.58 & 30.05 \\
Middle Swamp 1 & 87.00 & 28.05 \\
Middle Swamp 2 & 90.13 & 27.75 \\
Middle Swamp 3 & 92.00 & 26.20 \\
Middle Swamp 4 & 90.83 & 27.63 \\
Middle Swamp 5 & 81.00 & 29.51 \\
Middle Swamp 6 & 85.38 & 28.34 \\
Lower Swamp 1 & 81.00 & 30.25 \\
Lower Swamp 2 & 89.00 & 28.96 \\
Lower Swamp 3 & 83.75 & 28.70 \\
Lower Swamp 4 & 86.13 & 28.96 \\
Outskirt 1 & 69.92 & 32.10 \\
Outskirt 2 & 80.50 & 28.50 \\
Outskirt 3 & 76.63 & 32.19 \\
\hline
\end{tabular}

Cyclotus rostellatus (Pfeiffer, 1851), Fig. 2B

Cyclotus rostellatus is one of the rarer land snails found in Nee Soon freshwater swamp forest. Restricted to undisturbed forested areas, this snail has only been recorded in Nee Soon since 1990. The shell has a short sutural tube present near the aperture which is believed to aid in respiration in moist environments (Ho, 1995). All specimens were observed in moist areas with dense canopy cover.

Japonia ciliocinctum (Martens, 1865), Fig. 2C

Japonia ciliocinctum is mostly to be found foraging in the depths of the freshwater swamp forest. The shell is dull brown in colour with a hairy periostracum along the periphery. It has been speculated that the hairy periostracum might facilitate movement in a moist environment by relieving surface tension (Pfenninger et al., 2005). However, the hairy periostracum falls off easily upon handling. All observed specimens were found in swampy areas with a dense canopy cover.

\section{Family ACHATINIDAE}

Achatina fulica Bowdich, 1822, Fig. 2D

Achatina fulica is an invasive species originating from Africa and is commonly known as the Giant African Snail. In Nee Soon freshwater swamp forest shell heights of 7.5 $\mathrm{cm}$ or more have been observed. It is commonly found in parks and degraded forest but rarely in undisturbed forest. Unfortunately, several specimens were recorded deep 


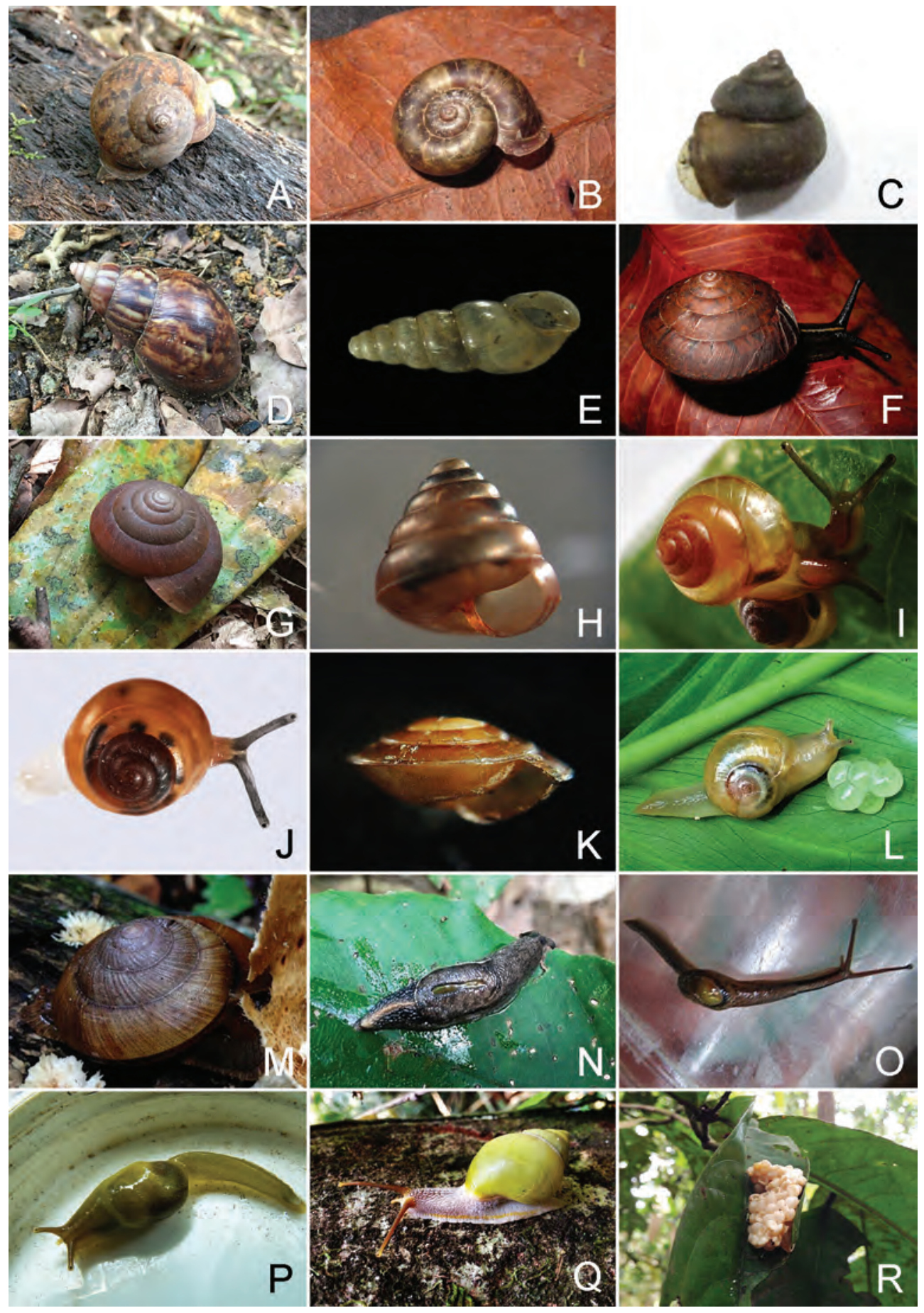

Fig. 2. A. Cyclophorus perdix aquila. B. Cyclotus rostellatus. C. Japonia ciliocinctum. D. Achatina fulica. E. Lamellaxis gracilis. F. Dyakia kintana. G. Quantula striata. H. Coneuplecta microconus. I. Liardetia convexoconica. J. Liardetia doliolum. K. Geotrochus lychnia. L. Helicarion perfragilis. M. Hemiplecta humphreysiana. N. Parmarion martensi. O. Microparmarion strubelli. P. Damayantia aff. simrothi. Q. Amphidromus atricallosus temasek. R. Amphidromus egg cluster. (Photos: A-H, K-R W.H. Lim; I-J Y.C. Ang) 
in the forest indicating that this species may have already established a population within Nee Soon.

\section{Family SUBULINIDAE}

Lamellaxis gracilis (Hutton, 1834), Fig. 2E

Lamellaxis gracilis is an introduced species found on the outskirts of Nee Soon freshwater swamp forest. It is likely to have spread from nearby plant nurseries and gardens. Although the species is easily confused with Subulina octona, it can be identified by its more slender shell shape and its columella is not truncated (Tan et al., 2012).

\section{Family DYAKIIDAE}

Dyakia kintana (de Morgan, 1885), Fig. 2F

Dyakia kintana is mostly found in undisturbed forest. It can be easily recognised by its sinistral coiled shell and the animal's body ranges from pink to white in colour with two black stripes. The periphery of the shell is acutely keeled. It has only been observed on the ground, hiding among leaf litter and fallen timber.

Quantula striata (Gray, 1834), Fig. 2G

Quantula striata is found commonly in urban areas as well as in the forest. Most of the specimens were observed in the outskirts of Nee Soon in close proximity to urban areas. Its shell colour is known to be variable (Tan et al., 2012); however only reddish brown examples were observed in Nee Soon freshwater swamp forest.

\section{Family EUCONULIDAE}

Coneuplecta microconus (Mousson, 1865), Fig. 2H

Coneuplecta microconus is a very tiny snail that was found near the outskirts of Nee Soon. The shell is conical in shape but unlike Liardetia convexoconica the periphery is acutely keeled.

Liardetia convexoconica (Moellendorff, 1897), Fig. 2I

Liardetia convexoconica is the most abundant species found in Nee Soon freshwater swamp forest. The shell is conical in shape and ranges from light brown to yellow in colour. The animal's body is yellow in colour with a tint of red on its head. It is arboreal and mostly found in shaded areas, hidden underneath the leaves.

Liardetia doliolum (Pfeiffer, 1846), Fig. 2J

Liardetia doliolum is a common species that can be found in both forested and urban 
areas. It has a tiny shell with distinct ribs on the outer surface. It has a lower spire than Liardetia convexiconica and its shell is dull brown. It was found near the outskirts of Nee Soon freshwater swamp forest.

\section{Microcystina sp.}

Microcystina is a tiny snail with a shell width of less than $3 \mathrm{~mm}$. The shell is glossy and brownish in colour. Only one taxon within the genus appears to be present within Singapore, but it was not attributed a species name by Ho (1995), nor is it here. Only three specimens were observed throughout the survey.

\section{Family TROCHOMORPHIDAE}

Geotrochus lychnia (Benson, 1852), Fig. 2K

Geotrochus lychnia is a very rare species that was only encountered twice during the survey, in both cases only as empty shells. Its shell has a small umbilical opening and its periphery is acutely keeled. Singapore is the type locality for Geotrochus lychnia.

Helicarion perfragilis (von Mollendorff, 1897), Fig. 2L

Helicarion perfragilis is an arboreal snail that is commonly found in open vegetation. The shell is very fragile and breaks easily. It was observed in rather high numbers near the outskirts of Nee Soon but none was recorded within the forest.

\section{Family ARIOPHANTIDAE}

Hemiplecta humphreysiana (Lea, 1841), Fig. 2M

Hemiplecta humphreysiana is the largest native snail found in Nee Soon freshwater swamp forest and can grow to a shell width of up to $5 \mathrm{~cm}$. The shell is brown with a dark brown stripe that runs along the periphery of mature specimens. Although, this species is commonly known to be found on algae covered logs and the forest floor (Ho, 1995), several individuals were observed clinging on to trees up to more than 2 metres high. It was observed feeding on fungus on many occasions. Singapore is the type locality for Hemiplecta humphreysiana.

Parmarion martensi Simroth, 1893, Fig. 2N

Parmarion martensi is a common slug found in many gardens and parks. Only two individuals were observed during the survey, at the outskirts of Nee Soon.

Microparmarion strubelli Simroth, 1893, Fig. 20

Microparmarion strubelli is restricted to forested areas with a dense canopy cover. Unlike other snails, its shell is reduced to a thin plate to which it can no longer retract for protection. Black markings are observed on the visceral hump. Only three specimens were observed throughout the whole survey. 
Damayantia aff. simrothi Collinge, 1903, Fig. 2P

Damayantia aff. simrothi is recorded for the first time in Singapore. However, available references and comparative material in Singapore are few and inadequate to provide determination of the species, thus the identification of the slug mentioned is provisional. Its body is yellow in colour and the mantle is smooth. Its foot is keeled with a series of ridges (rugae). It is likely to be arboreal as all the specimens were observed foraging on trees or underneath the leaves.

\section{Family BRADYBAENIDAE}

Bradybaena similaris (Ferussac, 1821)

Bradybaena similaris is commonly found throughout the moist tropics in urban areas such as gardens and plant nurseries. It is an agricultural pest and is most likely to have been introduced due to the horticultural and agricultural trade (Tan et al., 2012). It was observed in high numbers near the outskirts of Nee Soon but none was recorded within the freshwater swamp forest.

\section{Family CAMAENIDAE}

Amphidromus atricallosus temasek, Tan, Chan \& Panha, 2011, Fig. 2Q

Amphidromus atricallosus temasek is a recently described subspecies endemic to Singapore (Tan et al., 2011) and is restricted to forest within the Central Catchment Nature Reserve, Western Catchment (Chua \& Tan, 2015), Pulau Ubin (Tan \& Xu, 2013) and Pulau Tekong (Tan et al., 2015). Populations include individuals with both dextral and sinistral chirality. The ratio of dextral and sinistral specimens found is approximately 1:1 and interestingly both are well distributed within the swamp. This species is arboreal and spends much of the time up in the trees. It can sometime be observed on man-made concrete structures. A suspected egg cluster was observed during the survey (Fig. 2R).

Distribution of land snails

A total of ten families, 18 genera and 19 species of land snails were recorded from the 15 plots in Nee Soon. The data are shown in Table 2. Four species of snails: Dyakia kintana, Liardetia convexoconica, Hemiplecta humphreysiana and Amphidromus atricallosus temasek were identified as having a wide distribution within Nee Soon, being recorded in at least ten of the 15 plots. Four species of snails, Coneuplecta microconus, Helicarion perfragilis, Parmarion martensi and Bradybaena similaris were confined to the outskirts of Nee Soon. 
Species diversity and richness

The Shannon-Weiner Index ( $\mathrm{H}^{\prime}$ ) is commonly used as a measure for species diversity between habitats (Krebs, 1989). Based on the average H' calculated above for the 15 sampling plots (Fig. 3), the Lower Swamp 1 had the highest species diversity $\left(\mathrm{H}^{\prime}=\right.$ 0.53), while the Upper Swamp had the lowest species diversity $\left(\mathrm{H}^{\prime}=0\right)$. Many of the non-native snails are recorded in the Outskirts, reflected in a high H' but this does not reflect the true native diversity.

The Species Richness (R) indicates the average number of species present at each of the survey sites (Fig. 4). Based on the table above, Lower Swamp 1 had the highest species richness $(\mathrm{R}=4.5)$ and Upper Swamp 2 had the lowest species richness $(\mathrm{R}=0.33)$. The number of non-native snails recorded in the Outskirts distorts the species richness value there.

\section{Mean population abundance}

The three most abundant species found in Nee Soon freshwater swamp forest are Liardetia convexoconica, Helicarion perfragilis and Hemiplecta humphreysiana. All three species had a mean frequency of more than ten individuals per cycle of sampling (Fig. 5). However, six species of snails: Japonia ciliocinctum, Lamellaxis gracilis, Microcystina sp., Geotrochus lychnia, Parmarion martensi and Microparmarion strubelli are extremely rare in Nee Soon and had a low mean frequency of fewer than one per cycle of sampling.

\section{Discussion}

Studies on the land snails in Nee Soon freshwater swamp forest revealed a rich diversity despite the low abundance. Nineteen species of snails and slugs were recorded of which one species was documented for the first time in Singapore. Of the 19 species, 16 are native and three are introduced. Eight are forest dependent species: Cyclophorus perdix aquila, Cyclotus rostellatus, Japonia ciliocinctum, Dyakia kintana, Hemiplecta humphreysiana, Microparmarion strubelli, Damayantia cf. simrothi and Amphidromus atricallosus temasek, only observed in forested areas with a dense canopy cover. Introduced species are restricted to the outskirts of the Nee Soon freshwater swamp forest, with the exception of Achatina fulica on rare occasions.

It is not surprising that low abundance of land snails was observed due to the nature of a freshwater swamp forest. As it is well known that land snails have a high calcium requirement for the formation of their shells and eggs, the abundance of snails correlates with the soil calcium content (Graveland et al., 1994). However, Singapore's tropical soils are generally acidic and poor in calcium (Chia \& Foong, 1991), especially in freshwater swamp forest. Thus a shortage of calcium in Nee Soon soils (Nguyen et al., 2018) may be a limiting factor to the growth and reproduction 


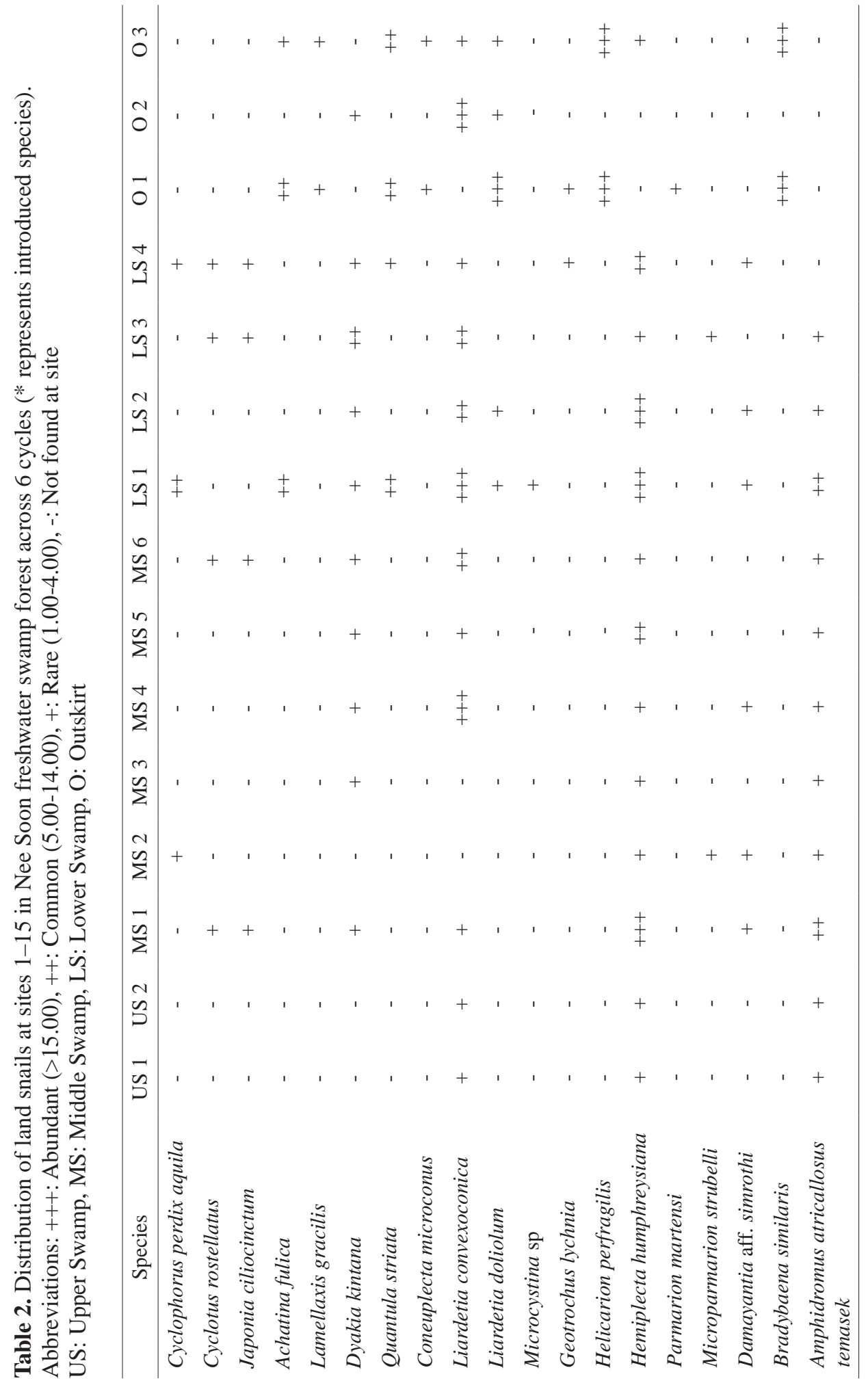




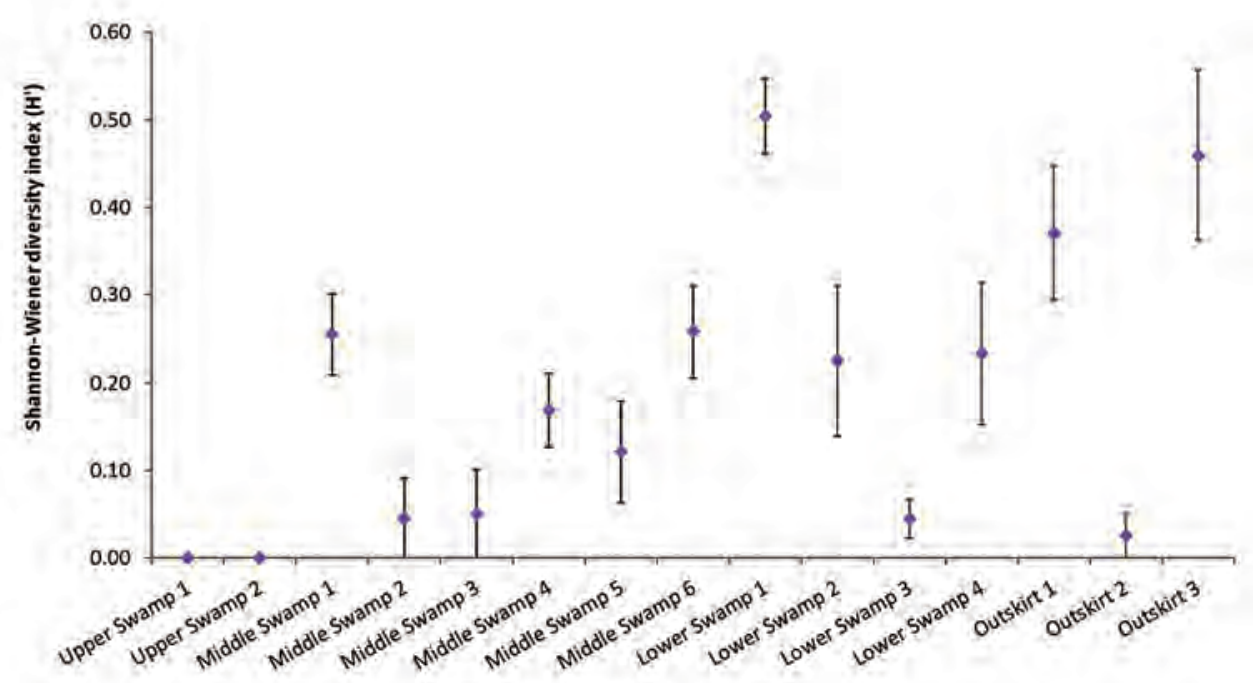

Fig. 3. Average Shannon-Weiner Index (H') of terrestrial snails and slugs at all survey sites.

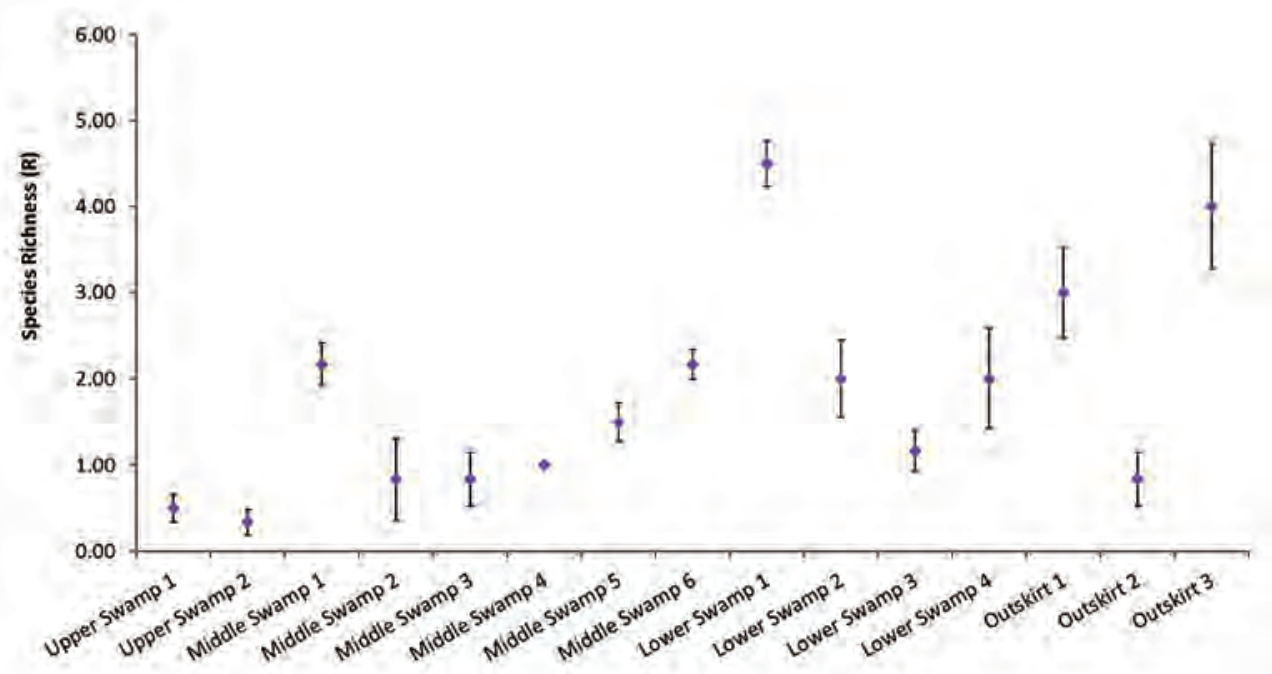

Fig. 4. Average Species Richness (R) of terrestrial snails and slugs at all survey sites.

of these land snails. The sampling method also plays a part in the observed low abundance. The handpicking sampling technique is limited, focuses sampling only from the ground level up to vegetation as high as two metres, and might miss very tiny or well camouflaged specimens. Many of the arboreal species that dwell in the canopy are not recorded. The lack of soil and leaf litter sieving sampling method also misses out on species that dwell within the soil. 


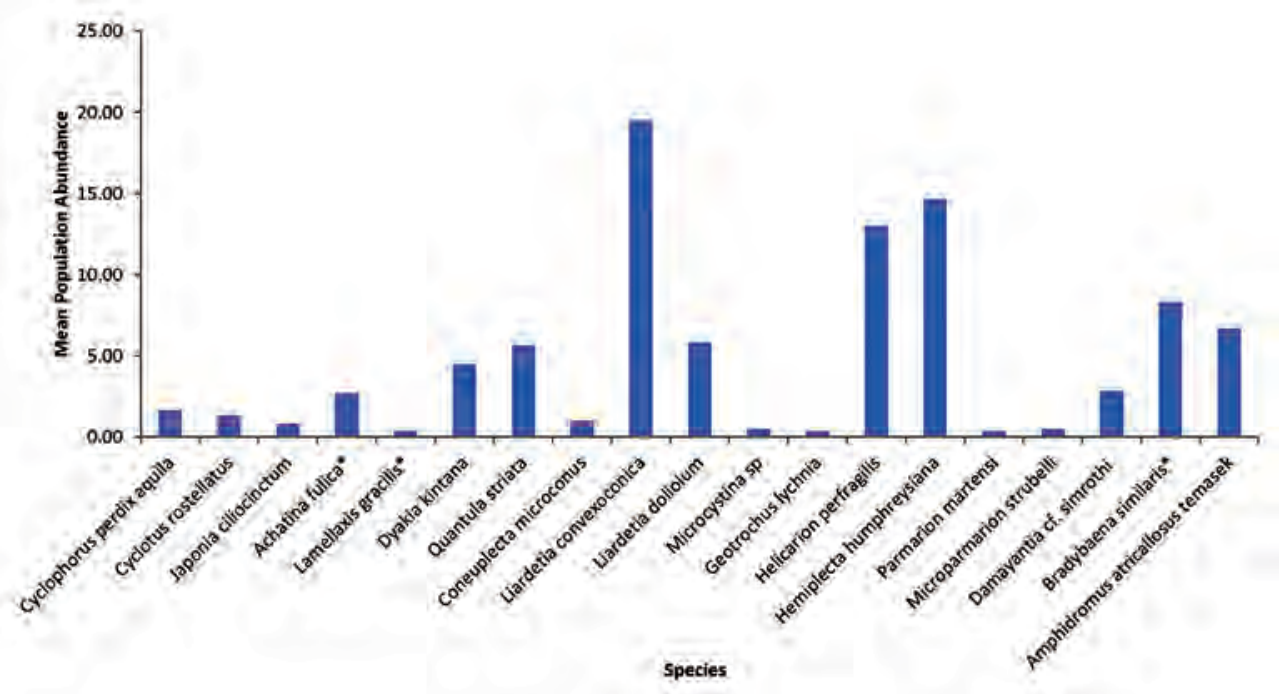

Fig. 5. Mean population abundance of terrestrial snails and slugs at all survey sites.

We observed that the relative moisture level of the area plays an important role in the distribution of the land snails. Based on the survey results, the Middle Swamp and Lower Swamp generally exhibit a higher diversity and richness as compared to the Upper Swamp. This may be due to the wetter and more humid habitat in the Middle Swamp and Lower Swamp. Many species such as Cyclophorus perdix aquila, Cyclotus rostellatus and Japonia ciliocinctum were only observed in partially waterlogged areas, in close proximity to forest streams. Thus, any change in the hydrology of the Nee Soon catchment may have adverse effects on the diversity and distribution of the land snails.

Nee Soon freshwater swamp forest is the last remaining freshwater swamp forest in Singapore. Not only does it harbour a rich diversity of land snails and slugs, it houses a significant population of the endemic Amphidromus atricallosus temasek. The discovery of the newly recorded Damayantia cf. simrothi also indicates that there may be more species waiting to be discovered. Unfortunately, the freshwater swamp forest ecosystem is extremely fragile, facing threats from environmental changes and urban development (Clews et al., 2018). Furthermore, the changes in global climate leading to extreme weather events will put additional stress on the forest (Sun et al., 2018). Unless measures and precautions are taken to safeguard the Nee Soon freshwater swamp forest, the rich biodiversity and heritage might be lost forever.

ACKNOWLEDGEMENTS. We would like to thank Drs Lena Chan and Geoffrey Davison for their support, Tan Siong Kiat for assistance in species identification and colleagues for helping in field surveys. This study forms part of the Nee Soon Swamp Forest Biodiversity and Hydrology Baseline Studies Project funded by the National Parks Board (FC 12302501). 


\section{References}

Chia, L.S. \& Foong S.F. (1991). Climate and weather. In: Chia, L.S., Rhaman, A. \& Tay, D.B.H. (eds) The Biophysical Environment of Singapore, pp. 89-133. Singapore: Singapore University Press for the Geography Teachers’ Association, Singapore.

Chua, M.A.H. \& Tan, S.K. (2015). Tree snail Amphidromus atricallosus temasek in Western Catchment Area. Singapore Biodivers. Rec. 2015: 9.

Clews, E., Corlett, R.T., Ho, J.K.I., Koh, C.Y., Liong, S.Y., Memory, A., Ramchunder, S., Siow, H.J.M.P., Sun, Y., Tan, H.H., Tan, S.Y., Tan, H.T.W., Theng, M.T.Y. \& Yeo, D.C.J. (2018) The biological, ecological and conservation significance of freshwater swamp forest in Singapore. Gard. Bull. Singapore 70 (Suppl. 1): 9-31.

Graveland, J., van der Wal, R., van Balen, J.H. \& van Noordwijk, A.J. (1994). Poor reproduction in forest passerines from decline of snail abundance on acidified soils. Nature 368: 446-448.

Ho, W.H. (1995). A Review of the Land-snail Fauna of Singapore. Raffles B. Zool. 43(1): 91-113.

Krebs, C.J. (1989). Ecological methodology, $2^{\text {nd }}$ ed. Menlo Park: Addison-Wesley Educational Publishers.

Ng, P.K.L. (1997). The conservation status of freshwater prawns and crabs in Singapore with emphasis on the Nature Reserves. Gard. Bull. Singapore 49: 267-272.

Ng, P.K.L. \& Lim, K.K.P. (1992). The conservation status of the Nee Soon freshwater swamp forest of Singapore. Aquatic Conserv. 2(3): 255-266.

Nguyen, C.T.T., Wasson, R.J. \& Ziegler, A.D. (2018). The hydro-geomorphic status of the Nee Soon freshwater swamp forest catchment of Singapore. Gard. Bull. Singapore 70 (Suppl. 1): 33-48.

Pfenninger, M., Hrabakova, M., Steinke, D. \& Depraz, A. (2005). Why do snails have hairs? A Bayesian inference of character evolution. BMC Evol. Biol. 5: 59.

Sun, Y., Kim, D.Y., Wendi, D., Doan, D.C., Raghavan, S.V., Jiang, Z. \& Liong, S.Y. (2018). Projected impacts of climate change on stream flow and groundwater of Nee Soon freshwater swamp forest, Singapore. Gard. Bull. Singapore 70 (Suppl. 1): 175-190.

Tan, S.K. \& Chan, M.K.K. (2013). Land snail Cyclophorus semisulcatus rediscovered at Bukit Timah. Singapore Biodivers. Rec. 2013: 4.

Tan, S.K. \& Chan, S.Y. (2009). New records of predatory slugs from Singapore with notes on their feeding behaviour. Nat. Singapore 2: 1-7.

Tan, S.K. \& Woo, H.P. (2010). A Preliminary Checklist of the Molluscs of Singapore. Singapore: Raffles Museum of Biodiversity Research, National University of Singapore, Singapore.

Tan, S.K. \& Xu, W. (2013). Tree snail Amphidromus atricallosus temasek on Pulau Ubin. Singapore Biodivers. Rec. 2013: 22.

Tan, S.K., Chan, S.Y. \& Panha, S. (2011). A new subspecies of Amphidromus (Amphidromus) atricallosus from Singapore (Mollusca: Gastropoda: Camaenidae). Raffles B. Zool. 59: 39-46.

Tan, S.K., Chan, S.Y. \& Clements, G.R. (2012). A Guide to Snails and other Non-marine Molluscs of Singapore. Singapore: Science Centre, Singapore.

Tan, S.K., Lim, K.K.P. \& Chua, M.A.H. (2015). Terrestrial snails and slugs (Mollusca: Gastropoda) of Pulau Tekong, Singapore. Nat. Singapore 8: 25-30.

Yeo, D.C.J. \& Lim, K.K.P. (2011) Freshwater ecosystems. In: Ng, P.K.L., Corlett, R.T. \& Tan, H.T.W. (eds) Singapore Biodiversity: An Encyclopedia of the Natural Environment and Sustainable Development, pp. 52-63. Singapore: Raffles Museum of Biodiversity Research, Department of Biological Sciences, National University of Singapore. 
